\title{
Developing an authentic project-based assessment model on sociology learning of senior high school students
}

\author{
Ike Sylvia', Syafri Anwar ${ }^{2}$, Khairani Khairani ${ }^{3}$ \\ ${ }^{123}$ Universitas Negeri Padang, Padang - Indonesia, (ikesylvia@fis.unp.ac.id)
}

\begin{abstract}
This article aims to describe an authentic project-based assessment model in improving students' Higher Order Thinking Skills (HOTS) on Sociology learning. This study used a mix-method design that applied ADDIE procedural to gain valid and reliable outcomes. Data collection used multiple techniques involving guided-interviews, survey, validity test, item instrument sheet, HOTS multiple questions with students' elicitation and observation sheet. The study results revealed that: (1) A characteristic of the authentic project-based assessment modelrefers toextensive assessments such as performance, attitude, presentation, product, project, and comprehension. Both performance and attitude assessments used during the project assessment. (2) An implementation of the authentic project-based assessment model is valid and reliable after givingan experimental treatmentin the class of X IIS SMAN 1 Padang that related to cognitive, affective and skills area. (3) An authentic project-based assessment model increased students' Higher Order Thinking Skills (HOTS) regarding critical thinking and problem-solving aspects, communication skill aspects, creativity and innovation aspects, and collaboration aspects.
\end{abstract}

Keywords: sociology learning, authentic assessment, higher order thinking skills (HOTS)

This is an open-access article distributed under the Creative Commons 4.0 Attribution License, which permits unrestricted use, distribution, and reproduction in any medium, provided the original work is properly cited. C2018 by author and Faculty of education, Universitas Negeri Padang.

\section{Introduction}

Educational and learning developmentis a subsystem of national development. A better quality of education and learning that takes place in and out of school, it will have a positive effect in human resources development. Also, it will be a productive workforce for the national development in the next period. On the other hand, education and learning are less qualified and less productive. It means that it will produce less qualified and less productive human resources.

In connection with it, UNESCO (1997: 86) formulated four pillars of education. It is learning to know, learning to do, learning to be and learning to live together. The four pillars are showing that education and learning cannot separate from individuals and their life. So, the individual as an education and learning product should be able to develop themselves fully and can live in a global society that is full of dynamics and competition.

In the 21st century life, a variety of skills should be mastered byan individual. It expected that educationprepares students to master some skills to become successful people in their life. The essential and necessary skills in the 21st century are critical thinking skills, collaboration skills, communication skills, creative and innovative thinking skills, anda variety of other skills consisting of 
problem-solving skills and metacognition. Therefore, some unique skills needed to empower in learning activities such as critical thinking skills, problem-solving, metacognition, communication skills, collaboration skills, creative and innovative skills, and information literacy.

In the21st century, updating and optimizing a learning quality is a necessityto improve and develop achievement. One of the learning strategies that usedis project-based learning(Weissinger, 2004; Arends, 2012). The project-basedlearningis an approach that focuses on student learning by giving the responsibility to complete the project so that learning is about a real-life situation (Arends \& Kilcher, 2010). The essential questions can assign an assignee to do an activity as a problem topic in a student method storing. It is the starting point for investigating and discovering(Arends, 2012) as well as for collaborating and managing tasks among students (Arends \& Kilcher, 2010). According to Arends (2012), a syntax of project-based learning will orient students to the matter, organize students to learn, guide individual and group investigation, develop and present project activities undertaken by students, analyze and evaluate the problem-solving process. It is also supported by McMahon (2007) who stated that the learning process by involving students in various activities showed an improvement of students' thinking skills regardingtheir critical and creative thinking. Also, students who got learning of the real-world setting can retain the knowledge longer than thosewho taught through traditional teaching. Even though, it may be less than traditional classroom learners.

In Indonesia,project-based learning is one of the strategies that recommended in the new curriculum. It has implemented since 2013. Ahigh-level thinking skill has not been able to be adequately implemented by teachers, especially Sociology teachers in West Sumatra. Although, the high-level capability is assumed to be useful for students. Some problems faced by educational practitioners at the moment regarding successful learning. Based on achievement of learning outcomes, it has been able to make a learning experience as a primary target of learning process and product. A learning assessment has not been able to provide a picture of students achievement. Therefore, the assessment of learning outcome did not providefeedback for students to develop their cognitive, affective, and skill optimally.

In principle, a learning process can mutually focus on learning outcomes. If the learning process focused on the acquisition of cognitive materials and values, itwould sort and position itself to focus on achieving a process score and learning outcomes (G. Brown, J. Bull, and M. Pendlebury, 1997). However, the development of thinking skills, character building, andstudents' skill would not realize if the learning has not been able to provide real feedback about student achievement in learning. While $90 \%$ of the valuegiven, it depends on what it is not visible, not only on a timedwritten exam but also a final report of material that their teacher assigns (P. Race and G. Brown, 2002).

Based on these problems, the concept of authentic assessment emerged in the early 1990s, as a form of expert dissatisfaction with the weaknesses of objective tests. Itmainlyassesseshigh-level cognitive skills in doing things in real life or real-world setting. According to John Mueller (2008), an authentic assessment is a form of assessment in which students asked to perform real-world tasks that demonstratemeaningful application of essential knowledge and skills. Therefore, the authentic assessment is a type or form assessment in which students perform, implement or perform a task in real life, not just with a written test at the end of the learning activities. The authentic assessment can bedone in various forms by the learning purposes such as observation, self-assessment, portfolio, authentic tasks, experiments, focused discussions, journals, analysis of events, and collaborating with each other through debates, and exhibitions. Therefore, an authentic assessment assesses not only the desired behavior, but also the attitudes, knowledge, skills, competence, and work processes in the context of real life as an integral part of the learning process. It happens to the student's life at school or society.

To tackle problems and optimize the achievement of national education objectives, the government launched the curriculum of 2013 with some purposes. It prepares Indonesian people to 
have the ability to live as individuals and citizens who are faithful, productive, creative, innovative, affective and capable contribute to society's life, nation, state, and civilization. One of the fundamental things that happened in Indonesian curriculum is a change in the learning assessment. The assessment is an essential part of learning. By conducting assessments, educators as manager of learning activity can determine the students' ability, the learning accuracy methods used, and the successful students in achieving the competence that has determined. Based on the assessment results, educators can make the right decision to determine the next step in making decisions. If the decision made from an incorrect appraisal result, there will undoubtedly be a mistake that may be detrimental to students or other related parties (Depdiknas, 2008).

By the curriculum of 2013, Sociology as one branch of Social Science given to high school requires the expertise of teachers to design, plan and carry out an assessment in Sociology learning. It is regarding primary competencies and indicators of achievement. Through a proper assessment, it can reveal students' competence in studying Sociology. It objectives some dimension such as content dimension, process dimension, context dimension, affective dimension and metacognition dimension. These competencies include knowledge, attitude, and skills in a comprehensive and sustainable.

In Sociology learning, an authentic assessment serves as a driver of learning activities and also to assess the students' learning process and outcomes. The authentic assessment in Sociology learning conducted comprehensively to assess leaning input, process, and output, which includes attitudes, knowledge, and skills. It alsoassesses the readiness of students, as well as the learning process and learning objectives as a whole. The assessment integration of three components (input - process output) will describe the students' capacity, style, and learning outcomes, even able to generate learning instructional effect and nurturant effect. In brief, this article aims to describe the research result on the implementation of authentic assessment instrument on project-based Sociology learning that expected to improve the ability of high-level thinking and $4 \mathrm{C}$ students.

\section{Method}

The development of authentic assessment instruments in Sociology at senior high school used Research and Development (R\&D). It focused on product development regardingthe authentic assessment instrument related toproject-based learning in social research material. This study enhances the students' ability of Higher Order Thinking Skills (HOTS) and 4C. The model development of authentic assessment instruments used ADDIE development model, with the stages of Analysis, Design, Develop, Implementation, and Evaluation.

Data collection techniques used to develop an authentic assessment instrument consists of interviews, tests, observation sheets and questionnaires. The interviews and observations conducted to obtain needs analysis data. Then, the researchers designed authentic assessment instruments. The authentic assessment instruments developed consist of cognitive assessment instrument (tests), attitude assessment (spiritual and social) in the form of self-assessment and peer-assessment instruments, skills assessment (performance assessment, project), classroom observation and field visits.

Validity and reliability test used to determine the effectiveness of cognitive assessment instrument designed to enhance students' HOTS. The validity and reliability tested through item analysis. Furthermore, the attitude and skill instruments validated by four expert validators, consisting of two experts of learning evaluation, one expert of Sociology material, one linguist and four Sociology teachers from several SMAN in Padang city. The expert validators validate the instrument by filling out a validation sheet used to determine the content validity, construct, language and practicalities of each developed instrument. A questionnaire regarding product usage used to obtain product practicalities data. 
Feasibility of authentic assessment instruments regarding the validity of students' affective, cognitive and psychomotor assessment instruments analyzed by using the Aiken V formula, as well as using alpha reliability coefficient for testing instrument reliability. Authentic instrumentsassessment that have been validated by experts are further improved and refined, so it deserves to test. To find out the effectiveness of the product development is done by four Sociology teachers and students of X IISwho are doing Sociology learning using Curriculum of 2013 in the second semester of academic year 2017/2018. This research conducted in class X IIS at SMAN 1 Padang consisting of 25 students.

\section{Results and Discussion}

Project-based authentic assessment is an integrated learning assessment. It takes place during the process and the end of a lesson. All of this project-based authentic assessment used a range of 1-4 rating to facilitate the assessment and reporting the learning outcomes according to the curriculum of 2013. The learning syntax adapted from project-based learning by integratingjudgment on the stages of project development. An assessment of the learning syntax showed inTable 1 below:

Table 1. The Learning Syntax and Assessment Types of Authentic Assessment Model Based on Project-Based Learning

\begin{tabular}{|c|c|c|c|}
\hline No. & Time Allocation & Learning Syntax & Type Assessment \\
\hline 1 & $\begin{array}{l}\text { The first and } \\
\text { secondmeeting }\end{array}$ & Start with the Essential Question & Attitude assessment \\
\hline 2 & $\begin{array}{l}\text { The third, fourth, and } \\
\text { fifth meeting }\end{array}$ & Design a Plan or the Project & Performance assessment \\
\hline 3 & & Tune the Project & Presentation assessment \\
\hline 4 & $\begin{array}{l}\text { The sixth and seventh } \\
\text { meeting }\end{array}$ & Do and Monitor Project Progress & $\begin{array}{l}\text { Performance assessment, } \\
\text { Attitude assessment }\end{array}$ \\
\hline 5 & $\begin{array}{l}\text { The eighth andninth } \\
\text { meeting }\end{array}$ & Exhibit the Project & $\begin{array}{l}\text { Product assessment, } \\
\text { Presentation assessment }\end{array}$ \\
\hline 6 & The tenth meeting & Evaluate the Experience & Knowledge assessment \\
\hline
\end{tabular}

The development of authentic assessment instruments on social research materials has been carried out through several stages byusing the development model of ADDIE. In the analysis stage, the researchers analyzed the assessment instruments used in four SMAN in Padang. Based on the initial analysis result, the instrument assessment on Sociology learning at senior high school prepared by teachers only focused on written test, either in the form of objective test or essay test. The written test measure students' cognitive aspects. According to Mueller's (2005), the assessment method should be able to measure all aspects that students know and do. It means that another type of assessment is needed to measure all aspects that students know and do can be measured. According to this situation, it is necessary to develop an authentic assessment instrument based on the performance and products performed by students in the learning process.

From the analysis result, it found that the existing assessment instruments do not fit to the standards of process assessment and students' learning outcomes regarding the curriculum of 2013. It showed the unavailability of the assessment rubric containing measurement indicators, measurement descriptors, and weighted scores. These used as a primary measurement of students' ability to solve problems in every aspect of competence (affective, cognitive and psychomotor), especially in social research materials. Based on the analysis results, the researchers analyzed needs analysis on the assessment objectives, techniques and forms of assessment, and assessment instrument by the standards assessment process and students' learning outcomes in the curriculum of 2013. It showed inTable 2 below: 
Table 2. The Results of Needs Analysis on Authentic Assessment Instruments

\begin{tabular}{|c|c|c|c|}
\hline $\begin{array}{l}\text { Competence } \\
\text { Aspects }\end{array}$ & Assessment Objectives & Assessment Techniques & Forms of Assessment \\
\hline $\begin{array}{l}\text { Attitude } \\
\text { (spiritual and } \\
\text { social) }\end{array}$ & $\begin{array}{l}\text { Value } \\
\text { Internalized } \\
\text { Character }\end{array}$ & $\begin{array}{l}\text { Self assessment } \\
\text { Peer assessment }\end{array}$ & $\begin{array}{l}\text { Questionnaires } \\
\text { (Rating Scale) }\end{array}$ \\
\hline Knowledge & $\begin{array}{l}\text { Understand } \\
\text { Apply } \\
\text { Analyze } \\
\text { Evaluate } \\
\text { Create }\end{array}$ & Written test & Objective Test \\
\hline Abstract skills & $\begin{array}{l}\text { Observe } \\
\text { Process } \\
\text { Present } \\
\text { Reasoning }\end{array}$ & $\begin{array}{l}\text { Performance assessment } \\
\text { Project assessment }\end{array}$ & Rating Scale \\
\hline Discipline skills & $\begin{array}{l}\text { Perception } \\
\text { Readiness } \\
\text { Imitate } \\
\text { Accustom } \\
\text { Into action original }\end{array}$ & $\begin{array}{l}\text { Performance assessment } \\
\text { Project assessment }\end{array}$ & Rating Scale \\
\hline
\end{tabular}

At the stage of design, the researchers prepared a schedule for producing products and determining validation team of experts consisting of four expert validators and four Sociology teachers. Also, the researchers set of product instrumentsassessment. It specially developed based on objectivesassessment, techniquesassessment, and forms of assessment for each aspect of student competence. The resulting design specifications include instrument shape, weighted score, and some assessment items. The components of $4 \mathrm{C}$ student's ability developed in this study showed in Table 3 below:

Table 3. The Development of Capability Indicators 4 C

\begin{tabular}{|c|c|c|c|c|}
\hline $\begin{array}{l}\text { Capabilities } \\
\text { Developed }\end{array}$ & Communication & Collaboration & $\begin{array}{l}\text { Critical Thinking } \\
\text { and Problem- } \\
\text { Solving }\end{array}$ & $\begin{array}{l}\text { Creativity and } \\
\text { Innovation }\end{array}$ \\
\hline Indicator & $\begin{array}{l}\text { - Demonstrate } \\
\text { - Exchange ideas } \\
\text { and explain } \\
\text { ideas }\end{array}$ & $\begin{array}{l}\text { - Work in } \\
\text { groups } \\
\text { - Discuss } \\
\text { - Transform } \\
\text { ideas } \\
\text { - Listen }\end{array}$ & $\begin{array}{l}\text { - Identify problem } \\
\text { - Formulate } \\
\text { problem } \\
\text { - Evaluate } \\
\text { performance } \\
\text { - Set options } \\
\text { - Analyze }\end{array}$ & $\begin{array}{l}\text { - Compare } \\
\text { - Evaluate } \\
\text { - Contribute ideas } \\
\text { into real world } \\
\text { - Solve problem }\end{array}$ \\
\hline
\end{tabular}

In the development stage, the product manufactured according to product specifications. Three groups of assessment instruments are the attitude instruments (affective), knowledge, and skills (psychomotor). These are gradually validated by the experts' assessment consisting of content validity, construct validity, linguistic, and practicalities. The expert'sjudgment results in the validity, linguistic and practicality aspects of three instruments assessments developed generally and worthy used. The feasibility criteria of project-based authentic assessment assessed from the validity level 
and average content of Aiken $\mathrm{V}$ is 0,775 . It means that it is a very goodcriterion. So, the data summary of experts judgment result showed inTable 4 below:

Tabel 4. The Summary of Product Validity Assessment by Experts Validator

\begin{tabular}{lcccc}
\hline \multicolumn{1}{c}{ Instruments Assessed } & $\begin{array}{c}\text { Average } \\
\text { Score }\end{array}$ & Criteria & Validity & Criteria \\
$\begin{array}{l}\text { Observation sheets of spiritual } \\
\text { attitudes observation }\end{array}$ & 42,4 & Very good & 0,77 & Valid \\
$\begin{array}{l}\text { Observation sheets of social attitudes } \\
\text { observation }\end{array}$ & 42,4 & Very good & 0,78 & Valid \\
$\begin{array}{l}\text { Self-assessment sheets } \\
\text { Peer-assessment sheets }\end{array}$ & 42,4 & Very good & 0,79 & Valid \\
Written test assessment sheets & 41,8 & Very good & 0,76 & Valid \\
Performance assessment sheets & 40,6 & Very good & 0,74 & Valid \\
Project assessment sheets & 41,2 & Very good & 0,79 & Valid \\
& 42,6 & Very good & 0,80 & Valid \\
\hline
\end{tabular}

A reliability test result used readability sheets by experts and teachers. Then, it analyzed by using interater test. It showed inTable 5 below:

Tabel 5. The Summary of Product Reliability Assessment by Experts Validator

\begin{tabular}{lcc}
\hline \multicolumn{1}{c}{ Instruments Assessed } & Reliability & Criteria \\
$\begin{array}{l}\text { Observation sheets of spiritual } \\
\text { attitudes observation }\end{array}$ & 0,809 & High \\
$\begin{array}{l}\text { Observation sheets of social } \\
\text { attitudes observation }\end{array}$ & 0,837 & High \\
Self-assessment sheets & 0,857 & High \\
Peer-assessment sheets & 0,498 & Enough \\
Written test assessment sheets & 0,845 & High \\
Performance assessment sheets & 0,764 & High \\
Project assessment sheets & 0,996 & High \\
\hline
\end{tabular}

An average of reliability rate is 0.800 . It means that it is a high criterion. In brief, the authentic instrument assessment developed was feasible and could be implemented.

In implementation stage, the instruments assessment that revised and declared eligible by experts tested on a small scale in ten students and two Sociology teachers. In trial result, it showed that an effective instruments assessment improved students learning outcomes. An average score of post-test is 78.21. An average score of peer assessment is 79.76. An average score of project task is 81.47. A final average score of the cognitive domain is 79.58. An average score of the performance test is 83.44 . An 
average of learning outcomes is 80.19. The practical assessment used based on students and teachers' response result. The small-scale revisions and trials used in large-scale trials.

To find out the feasibility of the instrument and to test the effectiveness of the product, a largescale trial conducted in four Sociology's teachers and 25 students of class X IIS SMA Negeri 1 Kota Padang as the subject of trials. The large-scale trials analysis results in a positive change of student learning outcomesdescribed as follows.The first, characteristic of a project-based authentic instrumentassessment suitable for high school students in Sociology subjects. It consists of performance appraisal (classroom discussion, discussion process assessment, and field survey observation), attitude assessment (peer assessment and self-assessment), presentation assessment, project and product assessment, and knowledge assessment. The performance appraisal and attitude assessment undertook during the project creation process. While the assessment of the presentation, project, product and knowledge assessment conducted at the end of the project activity.The second, achievement of Sociology competence in the implementation of project-based authentic instrumentassessment at class X IIS 1 on social research material showed3.0 (B) for a mean, $3.5(\mathrm{~B}+)$ for attitude assessment's mean, and 3.1 (B) for skill assessment's mean.

An assessment nature is an assessment to assess the process and student learning outcomes (Sudijono, 2011). Authentic assessment instrument proved to measure process and result of student learning. Pretestconducted at the beginning of learning that finds out the fundamental knowledge of the students. Posttest at the end of learning to know the impact of project-based learning. The project learning process is carried out to develop students' 4C skills, critical thinking skill, collaboration skill, communication skill, and creative and innovative thinking skills. Assessment instruments of the class discussion process, field survey observation assessment, peer assessment and attitude assessment conducted during class discussions and project-making process.While presentation assessment, project product assessment in the form of project appraisal or individual and group tasks, and knowledge assessment conducted at the end of project activities when students display their project results in front of the class.

The variety of instructional design makes students happy to follow the lesson. It showed by students' enthusiasm in every learning activity. The average descriptions of various ways of appraisal above, it showed that the average student experiences changes in learning outcomes. If the outcomes (observation, self-assessment, peers) and skills assessment (project appraisal and performance) are high, students with low posttest results would not necessarily have low learning outcomes. Conversely, students with high posttest results would not necessarily high learning results, if the outcomes donot balance the attitude and high skills. Indeed, there are groups of students whose cognitive learning outcomes have decreased. It proves that students who have high intelligence may not necessarily interact interpersonally and cooperate with peers. It also proves that they have not been able to internalize the values in Sociology learning into students' lives. So, their application of science to life is still lacking. The peer rating scores tend to be low. This finding is similar to the research conducted by Saad \& Boujaoude (2012) which states that students who have high test results, not always accompanied by high social skills.

Analysis of the practicality of authentic instrumentsassessment on large-scale trials conductedby student and teacher responses. The average student gave a positive response of $76.4 \%$ with good criteria for the application of this authentic assessment instrument. Data of student response support the responses they provide. The average students admitted happily to learn sociology, especially social research materials that studied in context. A person's affective aspect positively correlated with performance and organizational skills. However, it does not necessarily positively correlateto cognitive aspects (Meyer et al., 2002). Also, based on students questionnaire response, it found thatmajority of students who responded with very good categories also had good performance and project scores. 
Teacher response results obtained an average of $81.7 \%$. Based on the criteria of practicality Hobri (2009), the instruments are said to be practical if $80 \%$ of respondents or more in giving a positive response. From 4 teachers, two teachers responded with good criteria, andtwo teachers responded with very good criteria. However, the analysis of the questionnaire indicates that several things need to be improved to gain the practicality of using the instrument. It is because the instrument assessment considered to increase the burden on teachers. So, the teachers' willingness to apply the instruments in each material is still lacking. Other cause arethe lack of teachers' willingness, teachers' understanding and knowledge of the principle assessment and the learning pattern. Each teacher who has not applied the principle of authentic learning and high-level thinking does not characterize authentic assessment. Saad \& Boujaoude (2012) describes the relationship between the level of knowledge and teaching practices in the classroom. It can be anticipated by the socialization of the making and use of instruments so that teachers become accustomed to using assessment instruments.

In the evaluation stage, two aspects highlight in this study isthe development of authentic assessment instrument design and the impact use of authentic assessment instruments. The first, the authentic assessment instruments developed by the principles of authentic assessment. However, regarding implementation, the authentic assessments have a positive impact. If teachers also designed the learning based on real settings or authentic learning, students can feel a real learning experience. The use of this instrument requires considerable time to measure and assess every aspect of student competence incurriculum learning. More than one assessor who incorporated in the team teaching required to measure and assess every aspect of student competence who demonstrated by each student. However, if this authentic assessment instrument conducted in the learning process, it will bring the integration implications of all components such as affective, cognitive, and psychomotor. In brief, it provides feedback on student' self-development of students' hard skills and soft skills.

Based on the evaluation results, the use of authentic assessment instrument revealedthat (1) students' communication skills are better than indicators of exchanging ideas and explain ideas. (2) Authentic tasks of collaboration capabilities encourage the ability development to work in groups, discuss and transform ideas. (3) In critical thinking and problem-solving, this instrument measure some abilities such as (a) understand the problem, (b) plan for problem-solving, (c) solve problems according to plan, (d) evaluate problem-solving results, and (e) communicate problem-solving results. (4) In creativity and innovation, this instrument measure all the indicators developed and contributed the most excellent aspect of ideas into the real world.

\section{Conclusions}

Authentic assessment instruments designed and implemented in Sociology proved valid, reliable, practical and efficient. It developed in the aspects of knowledge, affective, and skills that are capable of enhancing students' Higher Order Thinking Skills (HOTS) and 4C (communication, collaboration, critical thinking and problem-solving, and creativity and innovation).The assignment steps in this instrument are designed and implemented in a real-world setting where students can collaborate to construct their tasks through the experience of learning. The surrounding social phenomena to be comprehensively integrated and holistically assessed the developing student ability. The assessment purpose provides feedback in improving the quality of learning process and teacher competencedevelopment. It also provides information for learners to be motivated to develop their ability. The assessment process in learning expected to accommodate cognitive, affective and psychomotor aspects of students.Because not all students have high cognitive both affective and psychomotor abilities, the learning process and assessment relate to the appraisal principles. These are the principle of continuity, comprehensive, fair and objective, cooperative and practical.

\section{References}


Anderson, L. W., \& Krathwohl, D. R. (2001). A taxonomy for learning, teaching and assessing: A revision of Bloom's taxonomy of educational objectives. New York: Longman.

Arends, R. I. (2012). Learning to teach (9 $9^{\text {th }}$ ed.). New York, NY: McGraw-Hill.

Arends, R. I., \& Kilcher, A. (2010). Teaching for student learning: Becoming an accomplished teacher. New York: Taylor \&Francis.

Bandura, A, (1986). Social foundations of thought and action:A social Cognitive theory: Englewood Cliffs, NJ: Prentice Hall

Brown, G., Bull, J. \& Pendlebury, M. (1997). Assessing Student Learning in Higher Education, London: Routledge.

Brown, S. \& Glasner, A. (1999). Assessment Matters in Higher Education, Buckingham: Open University Press.

Dekdiknas, (2003). Undang-undang Sistem Pendidikan Nasional, Jakarta: Badan Peneltian dan Pengembngan Depdiknas

Dick, W. \& Carey, L. (1990), The Systematic Design of Instruction, Third Edition, Harper,Collins

Fisher, R. (2010). Thinking Skill. In Arthur, J. \& Cremin, T. (Eds.), Learning to teach in the primary school ( $2^{\text {nd }}$ ed.). New York, NY: Routledge.

Gulikers, J., Bastiaens, T., \& Kirschner, P. (2004). A five-dimensional framework for authentic assessment,Educational Technology Research,and Development, 52 (3), 67-85.

Holbrook,J.\&Miia,R.2009.TheMeaningofLiteracy Sains. International Journal of Environmental ESainsEducation,Volume4No.3.Hal275-288.

Kemendikbud,(2017),Panduan Penilaian Oleh Pendidik dan Satuan Pendidikan Sekolah Menengah Atas,

Khaira, H.G. \& Yambo, D. (2005). The practicality of authentic assessment. Paper presented at The First International Conference on Enhancing Teaching and Learning Through Assessment. The Hong Kong Polytechnic University, June.

Krulik, S., \& Rudnick. J. A. (1999). Innovative Task to Improve Critical and Creative Thinking Skill. Dalam Stiff, Lee V. \& Curcio, Frances R.(Eds). Developing mathematical reasoning in grades K-12 ( $p p$. 138). Reston, VA: NCTM.

Liu, X. (2010). Essentials of science classroom assessment. Los Angeles: Sage Publication Ltd.

Lombardi, M. 2008. Making the Grade: The Role of AssessmentinAuthenticLearning.NewYork: Educause.

Majid,Abdul,(2015,Penilaian Autentik:Proses dan Hasil Belajar,Bandung:PT RemajaRosdakarya

McMahon, G. P. (2007). Getting the HOTS with what's in the box: developing higher order thinking skills within the technology-rich learning environment. Doctoral dissertation, Curtin University of Technology, Bentley, WestAustralia.

Meyer, J.P., David, J.S., Herscovitch L., \& Topolnytsky L. 2002. Affective, Continuance, andNormative Commitment to the Organization: A Meta-analysis of Antecedents, Correlates, and Consequences.JournalofVocationalBehavior, Volume 61 Hal20-52.

Mueller, J. (2006). Authentic assessment toolbox. Retrieved on 25th,June from the website:http://jonathan.mueller.faculty.noctrl.edu/toolbox/whatisit.htm\#looklike

Mueller, J ,2014, Authetic Assessmnet Tool,, North Central College, Naperville, IL

Peraturan Pemerintah No. 19 tahun 2005, yang disempurnakan dengan PP no 32, tahun 2013

Permendikbud No. 54 tahun 2013, tentang Standar Kompetensi Lulusan Pendidikan Dasar dan Pendidikan Menengah

Permendikbid No.64 tahun 2013, tentang Standar Isi Pendidikan Dasar dan Menengah.

Permendikbud No. 65 tahun 2013,tentang Standar Proses Pendidikan Dasar dan Menengah

Permendikbud No.66 tahun 2013 , tentang Standar Penilaian Pendidikan Dasar dan Menengah

Permendikbud No. 69 tahun 2013, tentang Kerangka Dasar dan Struktur Kurikulum Sekolah Menengah Atas/Madrasah Alyiah 
Prestidge, L. K. \& Williams Glaser, C. H. (2000). Authentic assessment: Employing appropriate tools for evaluating students' work in 21st-century classrooms [Electronic version]. Intervention in School \& Clinic, 35, 178-182.

Rust, c. (2002) The impact of assessment on student learning: how can the research literature practically help to inform the development of departmental assessment strategies and learnercentered assessment practices?, Active Learning in Higher Education, vol. 3, no. 2, pp. 145-158.

Saad, R. \& Boujaoude, S. 2012. The Relationship between Teachers' Knowledge and Beliefs about Science and Inquiry and Their Classroom Practices. Eurasia Journal of Mathematics, Science \& Technology Education, Volume 8 No. 2. Hal 113-128.

Setiadi,Elly.M \& Kolip, Usman, 2011,Pengantar Sosiologi, Jakarta: Kencana, Prenada Media Group

Soekamto,S., 1986, Sosiologi Suatu Pengantar, Edisi ke -2,Jakarta :Rajawali Press

Stiggins, R. (2001). Student-centered classroom assessment ( $3^{\text {rd }}$ ed.). Upper Saddle River, NJ: Merrill Prentice Hall.

Sudijono, Anas. (2011). Pengantar Evaluasi Pendidikan, Jakarta:Raja Grafindo Persada

Tanner, D. E. (2001). Authentic assessment: A solution, or part of the problem? High School Journal, 85, 24-29. Retrieved May 19, 2004 from EBSCO database.

Tombari, M., \& Borich, G. (1999). Authentic assessment in the classroom: Applications and practice. Toronto, ON Prentice-Hall.

Undang-undang Pendidikan Nomor 20 Tahun 2003 tentang Sistem Pendidikan Nasional

Weber, E. (1999). Student assessment that works: A practical approach. Boston: Allyn and Bacon.

Weissinger, P.A. (2004). Critical thinking, metacognition, and problem-based learning. In Tan, O.S. (Eds.), Enhancing thinking through problem-based learning approaches: international perspectives. Singapore: CengageLearning.

Wiggins, G. P. (1993). Assessing student performance: Exploring the purpose and limits of testing. San Francisco: Jossey-Bass. 